\title{
Histological study of the Vagus, Accessory and Hypoglossal nerves nuclei in one humped camel Camelus Dromedarius
}

\author{
T.A.Abass \\ Dept. of Anatomy and Histology-College of Vet. Med. - Baghdad University \\ Iraq
}

\begin{abstract}
Summary
The present work making histological studies of certain part of medulla oblongata on seven one humped camel ( Camelus Dromedarius ) of different ages and sexes. The location of Vagus X, accessory XI and hypoglossal XII nerve nuclei. The hypoglossal nerve XII nucleus consist of two nuclei dorsal greater and ventral smaller and the dorsal nuclei observed. Connected with dorsal motor vagal nucleus $X$ by specific arch of fiber in many sections and another observation the root fiber of hypoglossal nucleus XII pass along the lateral border of inferior olivary nucleus and some sections the root fiber penetrate lateral part of inferior olivary nucleus.
\end{abstract}




\title{
دراسة نسيجية للعصب الحائر , الأضافي والتحت اللساني للجمل ذي السنام الواحد Camelus dromedarius
}

\author{
ثامر عبود عباس \\ فرع التشربح والانسجة-كلية الطب البيطري- جامعة بغداد- العراق
}

\section{الخلاصة}

ان البحث شمل الدراسة النسيجية لبعض اجزاء النخاع المستطيل لسبعة ادمغة لحيوان الجمل ذو

السنام الواحد بمختلف الأعمار والجنس • ولقد لوحظ ان موقع الأنوية العصبية للعصب التائه,العصب الأضافي والعصب تحت اللساني مشابهة لبقية الحيوانات. لكن حيوان الجمل تميز بوجود اختلاف عن بقية الحيوانت وذللك بان نواة العصب تحت اللساني تتكون من نواتين( ظهرية) كبيرة و (البطنية )صغيرة , كما ان النواة الظهرية تتصل بالنواة الظهرية الحركية للعصب النائه بواسطة قوس ليفي يستمر لعدة مقاطع. كما لوحظ ان جذور الياف العصب تحت اللساني تمر بطنيا ووحشيا لنواة الزيتونية السفلية ولوحظ في بعض المقاطع ان هذة جذور الياف تخترق النواة الزيتونية السفلية من الجهة الوحشية للنواة وان هذة الصفات قد انفرد بها حيوان الجمل ذو السنام الواحد عن بقية الحيوانات

\section{Introduction}

Work has been in progress in our neuroanatomy laboratory on the structural and functional nuclei of the central nervous system in camel. This is a continuing study and deals with the quantative morphological study of the neurons (cells) of the nuclei. To investigate the disease of the central nervous system, it is essential to examine the nuclei in brain stem like the nuclei Vagus, accessory and hypoglossal nerves. These nuclei in camel are closely resembling the nuclei of other domesticate mammals (23). We feel this simple guide helps anatomists and comparative pathologists.

Early study was conducted on these nerve nuclei in avian (1), and the internal structure of the medulla oblongata in sheep (2), and the comparative anatomical studies in mammals in reticular formation ( $3 \& 4)$, also (5) take observation by degeneration of nerve by rhizotomic, while (6)(12) study the solitary nucleus in Cat.

The cytoarchitecture of the brain by using serial sections of all brain stem (7), in Pig (11); studying reticular formation in brain stem in rats (8). These 
nerve are us trigeminal tractomy in monkey (9), the ambiguus nucleus was studied by cutting the glossopharyngeal branches in rabbit (10), in rat(14) studying the dorsal motor vagal nucleus in pigeon By cervical vagotomy and observing degeneration (13), and sheep (16), in rat (14), cat (20), and other animal horse, dog, cat, pig, sheep and goat(17),(16)(21) and with ambiguus (10), and by using cholensteraus in rat (14) the investigation all nuclei in medulla oblongata, found arch of fiber tracts between Vagus and hypoglossal nucleus, and now using immuno-histo-chemical examination axonal, preganglionc neuron in rat(24) the roots of hypoglossal nuclei in camel penetrate the inferior olivary nucleus (23) finally not forget this studying are make in humenbeing (18),(22)

\section{Materials and methods}

In this study were used seven brain of one humped (Camelus Dromedarius), of different ages and sexes, obtained from Najaf slaughter house. It take the skulls of camel and after slaughter remove the bone of skull and embedded in $10 \%$ formaline for 3 weeks and then take spinal cord and medulla oblongata, and cutting serial section by frozen microtome $40 u$ and every $20^{\text {th }}$ section was stain with toludin blue and left in plate over night and than fixed in special glass slid and examined by a light microscope.

\section{Result}

- Vagus nerve $X$ :

The Vagus nerve a mixed nerve associated with four nuclei in medulla oblongata:-

\section{Dorsal motor nucleus of the Vagus $X$.}

This nucleus in camel extended from the cranial extremity of inferior olivary nucleus to the junction of spinal cord with medulla oblongata ( Fig 1,2,4 ).

The nucleus located dorso- lateral to central canal and dorsal to hypoglossal nucleus XII (Fig 1,2,4); and takes more lateral location to XII nucleus in floor of fourth ventricle; the nucleus it is more longer than the XII nucleus and intercalate nucleus ( Fig 2,4 ), (it located between X, XII nucleus ).

This nucleus is characterized by three type of cell, large multipolar shape with nucleus and dark nuclei and dark Nissle bodies, the other is medium spindle or 
conical shape with central nucleus and scatter Nissal bodies, the later cell is small a rounded or oval with central nucleus with dark Nissle bodies.

\section{Nucleus ambiguous.}

This is also known as ventral motor nucleus of Vagus $X$. This nucleus in camel extended as continuous of accessory nucleus XI caudally till reach rostral part of the medulla oblongata, the nucleus located medial to spinal tractus of trigeminal $\mathrm{V}$, i.e. ventro-lateral to medulla oblongata (Fig 2,4 ). This nucleus may contain few cells, so it is very difficult to differentiated from reticular cells in some plane. The ambiguus nucleus in camel represented as the source of roots of glossopharyngeal IX, Vagus X , accessory XI nerve which pass ventrolateral of nucleus transvelly to spinal tract of trigeminal $\mathrm{V}$ nucleus to emerge from lateral surface of medulla oblongata. This nucleus have cells contain central nucleus with dark Nissle bodies.

\section{Nucleus of spinal tract of trigeminal $V$.}

This nucleus extends rostrally from the level of caudal pole of the inferior olivary nucleus to plane through the caudal pole of the nucleus facial nucleus VII. The nucleus located dorsally and laterally of medulla oblongata (Fig 2,4).

The nucleus comprising cells rounded, Spindle which small and medium size, while the larger size is stellate cells with dark nucleus and Nissle bodies

\section{Nucleus Soltarius.}

This nucleus in camel extended from pyramidal decussation .It located dorsolateral to central canal; dorsal and paraller to dorsal to dorsal motor Vagus nucleus X (Fig2, 4). This nucleus have three types of cells large multipolar and medium it is spindle and small oval, each cells contain dark nucleus with Nissle bodies .

This nucleus represented as a source of fiber roots of glossopharyngeal IX, Vagus $\mathrm{X}$ and facial VII nerve.

- Accessory nerve XI

The accessory nerve in camel have two roots, the spinal and cranial roots arise from the caudal pole of the nucleus ambiguus in medulla oblongata. The nucleus located in camel in caudal portion of medulla oblongata, ventral to spinal tracts of Trigeminal $\mathrm{V}$ nucleus and it is cranial part of nucleus it continuous of along the dorsal horn of grey matter of cervical segment and along the ambiguus nucleus cranially ( Fig 1). 
This nucleus contain cells characterized by larger multipolar neuron with central nucleus and dark Nissle bodies.

This nucleus due to scatter cells, it's difficult to differentiate it from cells of reticular formation in some regions . lateral reticular nucleus this nucleus in camel is one of prominent nucleus in reticular formation in medulla oblongata . it extended from caudal pole of facial nucleus to caudal pole of inferior olivary nucleus .

It is located lateral to olivary and pyramids (Fig2,4). This nucleus contain large multipolar it located dorsal of nucleus, while in ventral of nucleus it contain mostly of medium and small cells. Here must explain the inferior olivary nucleus.

This nucleus extended through obex i.e. from cranial to caudal obex. It located dorso-lateral to pyramid, this nucleus divided in camel into principle dorsal accessory and ventral accessory part $($ Fig 2,4$)$

\section{- Hypoglossal nerve XII}

In this study appear that hypoglossal nucleus XII extended from pyramidal decussation caudally to the plane caudal of cranial pole of dorsal motor vagal nucleus. This extension appears that the hypoglossal nucleus XII pass paraller to Vagus nerve nucleus in one side (Fig1, 2, 3, 4). In other side it is shorter than Vagus nucleus $\mathrm{X}$. Through investigation the section found in camel that caudal pole of nucleus located ventro-lateral to central canal and ventrally to dorsal motor vagal nucleus (Fig1,2,3,4).

The hypoglossal nucleus XII it contain two nuclei dorsal and ventral nuclei, dorsal it is greater than that ventral nucleus which appear in caudal part of medulla oblongata, and suddly disappear in cranial section, ventral nucleus contain small cell triangular or conical shape cell with central nucleus with dark Nissel bodies. While the dorsal nucleus it characterized by large cell and giant cell and small cells. The large, it is multipolar stelate with central nucleus and dark nuclei with Nissle bodies. The giant cells it is scatter like large cell in shape while small cells is few oval in shape.

The dorsal nucleus it is arising fiber rootlets which is a cheif source of hypoglossal XII nerve which pass toward the ventro- medial margin of this cells group, here they become combined to form well marked nerve strands, which than pass obliquely ventral and lateral to reach the peripheral approximately along the lateral border of the inferior olivary nucleus. In some section it penetrates the inferior olivary nucleus. 
It is only in camel found that is the significant properties in camel(Fig 2,4). Between this strands or fasciculus it is accumulation of cells median and small cells in size, this cells called inter fasciculus hypoglossal nucleus, another nucleus observated in cranial extremity or pole of hypoglossal nucleus XII it is accumation of cells large and medium and small cell oval or spindle in shape, while the larger it is multipolar this cells form nucleus named prepositus hypoglossal nucleus (Fig 4).

The another more important thing it show the arch of fiber between dorsal motor vagal nucleus X and hypoglossal nucleus XII (Fig 1).

This arch clear in some distant of the nucleus, this arch play important role in combination of two nucleus X, XII and the function of this arch must study by the neurosurgeon and

Neurophysiologic authors to explain the relationship between two nuclei in camel, the camel which face suffering weather through walking through out the hot desert.

\section{Discussion}

\section{Vagus nerve nuclei $X$}

The Vagus nerve nuclei in camel dorsal motor vagal nucleus, it is located dorsal to central canal it is same location in Birds (2), Rats (14), other Mammals (19), Cats (7) and in Equine (17).

While the shape of cells in this nucleus, large multipolar it is also found in Cat (20),(7), Pigeon (13), while in Human being, Rats and Sheep, the large cells it is scatter (14),(18).

The ambguus nucleus in camel it occupy, the same region in medulla oblongata of camel like Equine (17), Human being (18) and other animal (21), while the shape and size of ambiguus cells in camel, it refers also in $\operatorname{Sheep(2),Cat(7),~}$ Rabbit (10), Rat (14), Pig (11).The ambguus it is source of fiber root of glossopharyngeal XI, Vagus X, accessory XI nerve it found in Rabbit (10) and Sheep (16).

The solitorii nucleus in camel it is like in Sheep (2), Cat (7) and Pig (11). the solitorii nucleus it is the origin of fibers of facial VII , Vagus $\mathrm{X}$ and accessory $\mathrm{XI}$ it refers also in (17),(5).

2. Accessory nerve nucleus XI 
The accessory nucleus in camel, it is location in medulla oblongata also mention in Equine (17), Human being (18) and other animal (21)and it is cells shape in camel also refers in Sheep (2).

The hypoglossal nucleus XII in camel takes the same location in all animal except in Human being it located lateral to central canal (18). The hypoglossal nerve in camel have two nuclei dorsal and ventral nuclei is similar in bird (7), but in camel the dorsal nucleus it is greater than the ventral nucleus, while the other animal have only one nucleus of hypoglossal nerve XII .

The cell shape of hypoglossal nucleus XII . It is smaller in studying in sheep (2) and human being (18), but differ in Cat have not small size cells (7). The rootless of hypoglossal nerve nuclei XII in camel it direction ventro - lateral of inferior olivary nucleus (7),(2),(18) and (11).

The fiber it penetrates the inferior olivary nucleus it is only show in camel and have invite all authors in neuroscience to study or experimental in vestigation to explain the relationship of hypoglossal and inferior olivary nucleus.

About the arch of fiber of band connection between dorsal motor vagal nucleuses and hypoglossal nerve nucleus XII. It is significant observation in camel and also here I dept the neuro - surgery and neuro - physiology authors to research about this arch by experimental vagoectomy of nerve and seen degeneration of nucleus and describe the function of two nucleus to organ innervations in chest and abdominal cavity.

Finally the prepositus_ hypoglossal nucleus XII in camel it is also found in Sheep (2) and Cats (7).and also intercalated nucleus in camel it is similar in all animal except in Pigeon (13). While the shape of cells in camel it is like in Cat (7) and differ in Human being (18) and sheep (2). 
Iraqi Journal of Veterinary Medicine Vol. 32, No. 2, 2008

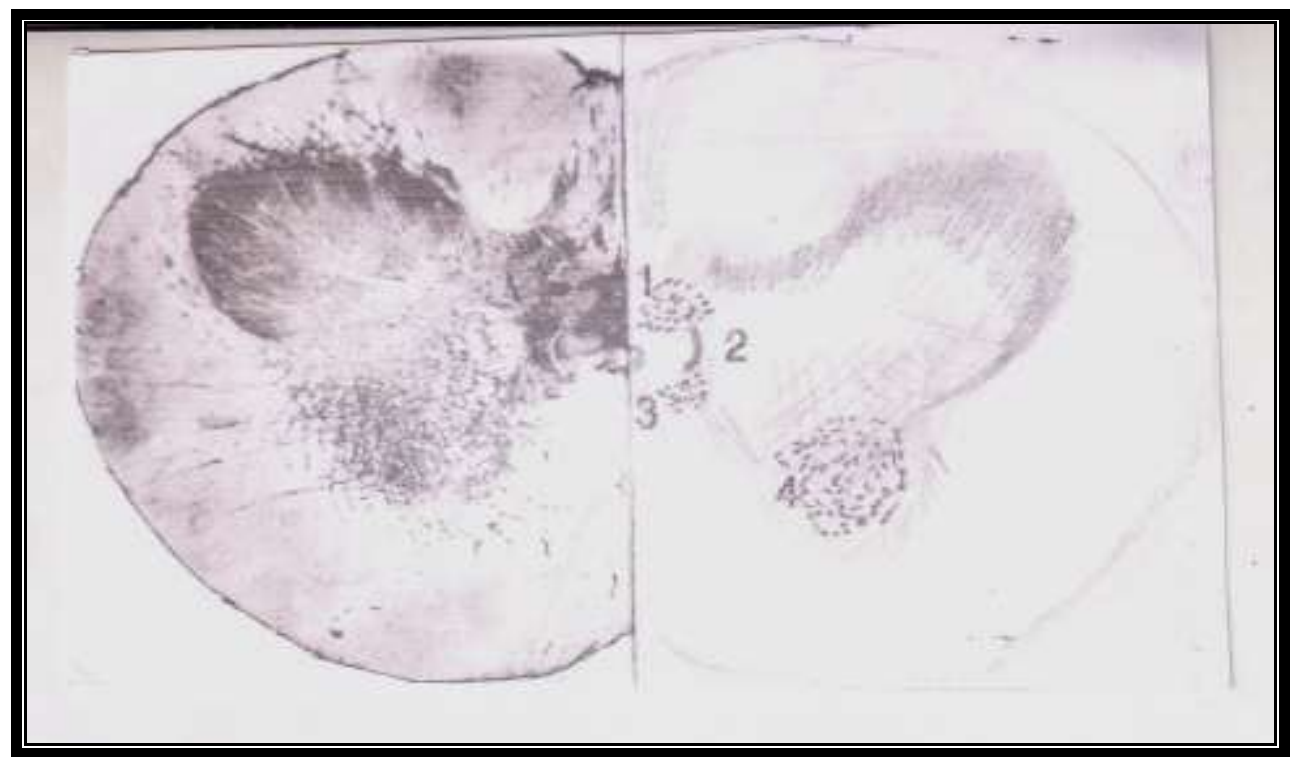

Fig (1): caudal region of medulla oblongata $X 12$ show nuclei around central canal and arch

1. Dorsal motor vagal nucleus $\mathrm{X}$

3. Hypoglossal nucleus XII
2. Arch of fiber

4. Accessory nucleus XI

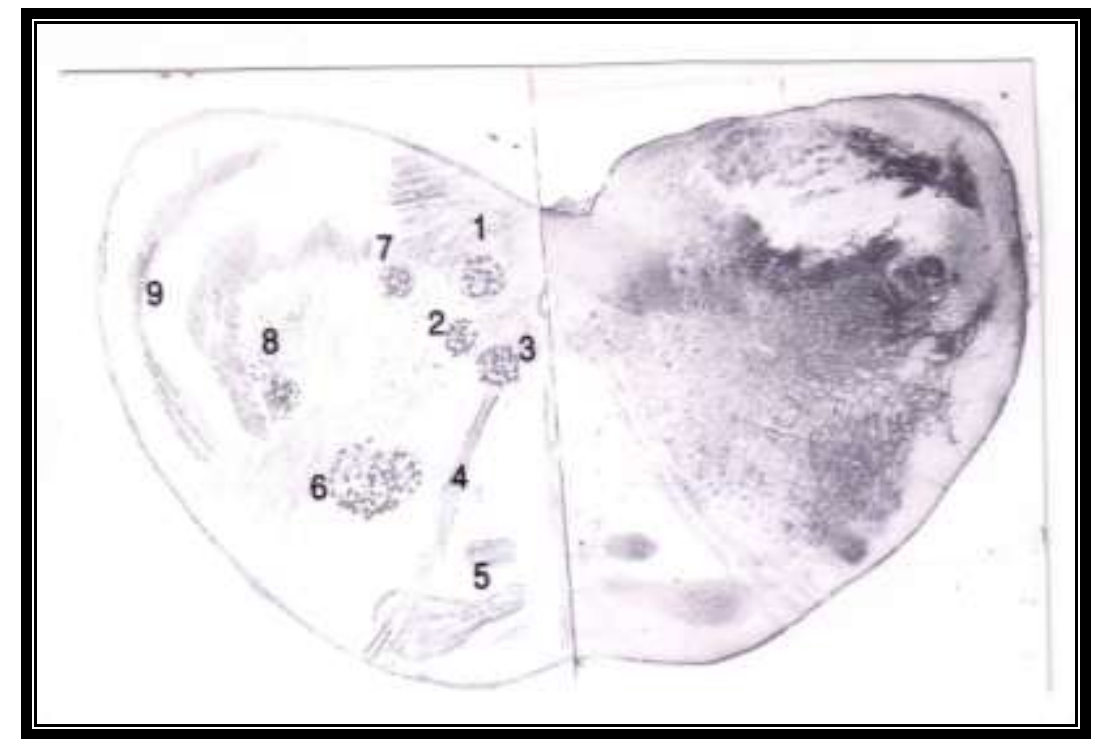

Fig (2): caudal obex X 12 


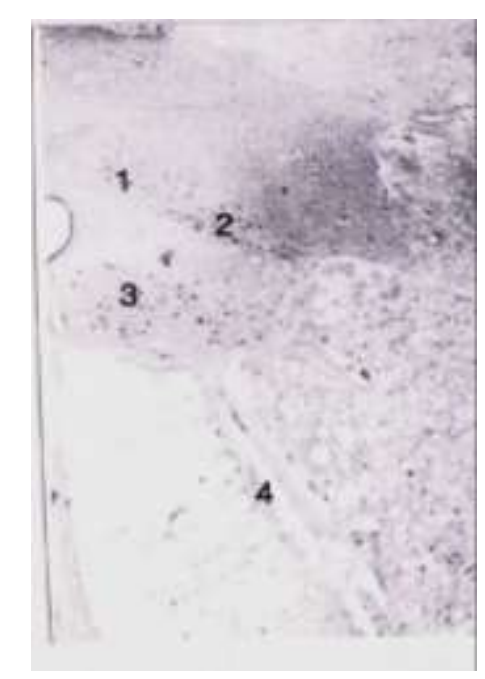

\section{Fig (3): magnification of part from (Fig2)}
1- Dorsal motor vagal nucleus X 2- Intercalated nucleus
3- Hypoglossal nucleus XII
4- Root fiber of XII nerve
5- Inferior olivary nucleus
6- Lateral reticular nucleus
7- Soltarius nucleus
8-Ambiguus nucleus

9-Spinal tract of trigeminal $\mathrm{V}$ 
Iraqi Journal of Veterinary Medicine Vol. 32, No. 2, 2008

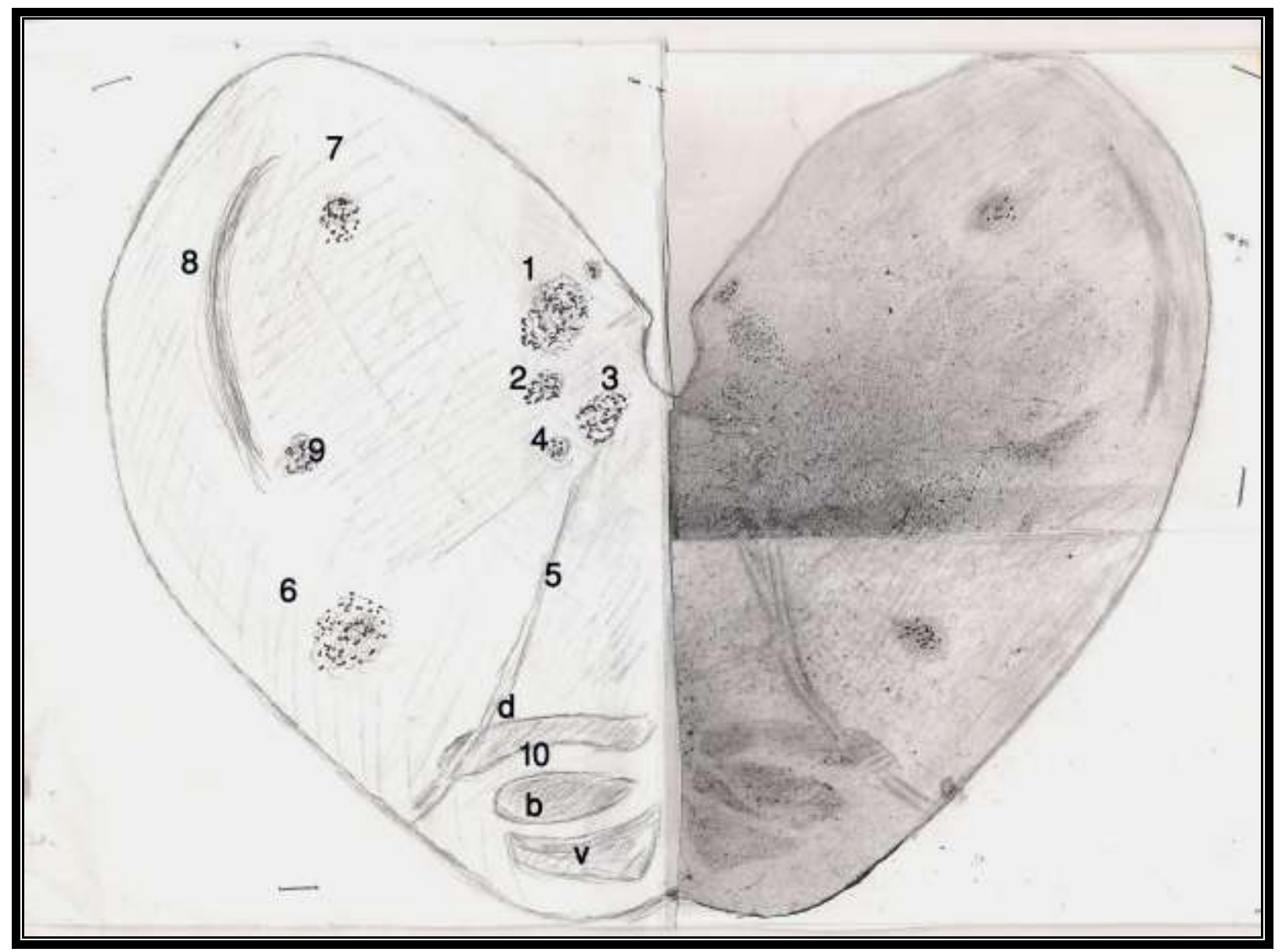

Fig(4) :cranial obex X 12

1- Dorsal motor vagal nucleus X 2-Intercalated nucleus

3- Hypoglossal nucleus (dorsal nucleus) 4-Hypoglossal nucleus (ventral nucleus)

5- Root fiber of hypoglossal nerve 6- Lateral reticular nucleus

7- Soltarius nucleus 8- Spinal tract of trigeminal V nucleus

9- Ambguus nucleus

10- Inferior olivary nucleus

d- Dorsal b- principle v- ventral 


\section{Iraqi Journal of Veterinary Medicine Vol. 32, No. 2, 2008}

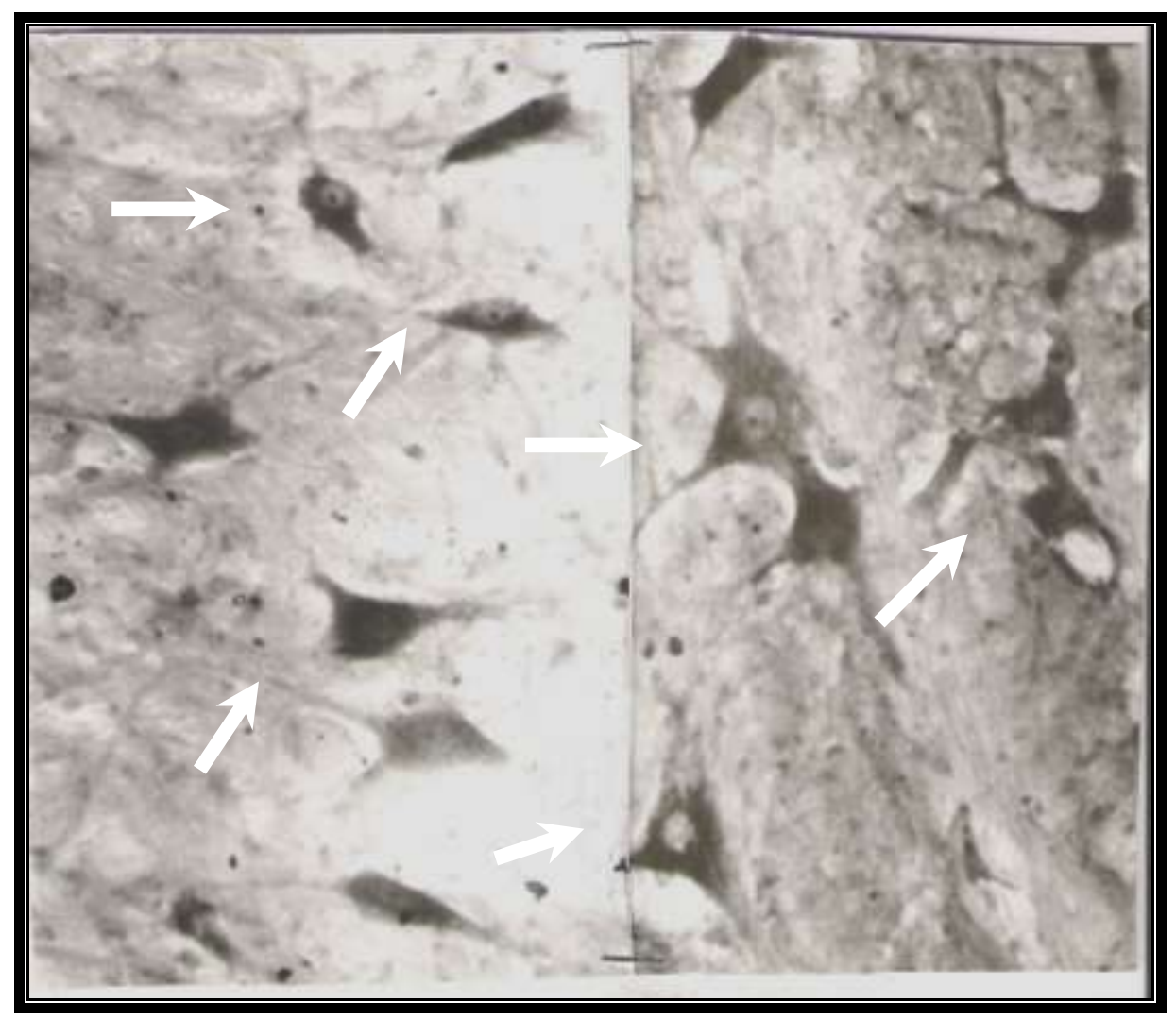

Fig (5: shape of multipolar neuron X 25

\section{Refrence}

1. Black,D. (1922) The motor nuclei of cerebral nerve in phylgeny, A study of phenomena of neuro biotaxia. J. comp. Neur. 34:233.275

2. Pattison and Holman, H.H. (1943). A count of nuclei in the medulla oblongata in sheep -J.comp. path. 53:130-139

3. Walbarg, F. (1952) Lateral reticular nucleus in medulla oblongata in mammalis. Comparative anatomical study. J.comp. Neur 96:285-343

4. Valverd, F. (1961). Reticular formation of pons and medulla oblongata. A colgi study.J.comp. Neur 116:71-99

5. Kerr, F.W.I .and Rochester, M. (1961). Structure relation of trigeminal spinal, tract to upper cervical root and solitary nucleus in Cut.Exper. neural 4:134-148

6. Szteyn, S. (1962). nuclei in medulla oblongata in Monky. Nutria Animals. Univ. Marie-curie, Skodowaska 17:21-43. 
7. Taber, E. (1962).The cytoarchitecture of brain stem of the cat.I.Brain stem nuclei of Cat. J.comp. Neur. 116:27-70

8. Valverd, F. (1962). Reticular formation of albmorats brain stem. Cytoarchitecture and corticofugal connection. J.comp. Neur 119:25-48

9. Arthur, J. (1964).The position of cutaneous component of the facial, glossopharyngeal and vagus nerve in spinal tract of V. J. comp. Neur 122:389394.

10.Lawn, A. M. (1966).The nucleus of ambiguus of Rabbit J. comp. Neur 127:307320

11.Breazile, J. E. (1967). Cytoarchitecture of brain stem of domestic Pig. J.com. Neur129:169-180

12.D. Kent, Morest. (1967). Experimental study of the projections of nucleus of the tractuus solitarius and the area postrema in the Cat. J.comp. Neur30:277-300

13.Cohen, D,.H., Adrian, M.S. and Robert, L.M. (1970). Medullary cel of origen of vagal cardiomhibitory fiber in Pigeon .J.comp. Neur 140:299-320

14.Lewis, D.R.; Scott, J.L. and V. Navarthan(1970). Localization in dorsal motor nucleus of Vagus. In Rat .A. Anatomy 107:197-208

15.Bowman ,J. P. and John, R. S. (1973). Morphogy of inferior olivary complex of the Rhasus Monky (Macaca Mulatta).J.comp. Neur 152:299-316

16.Welento,J. and stainslaw, F. (1974). Distribution of nerve center in nucleus dorsalis nerve Vagi and $\mathrm{V}$ ambiguus in the Sheep. Polskie Archvum Weterynaryine 17:7-24

17.Dellman, H. D. and McClure, R.C. (1975). Central nervous system Ed. Getty. pub, W. B. Sanaders comp. Philodelphia, London

18.Carpenter, M. B. (1976).Human neuroanatomy (7th Ed.). pub WILLEM \& WILKINS comp. Baltimore

19.Kitchell, R. L. and Stromberg, M. W.;L.H. Davis.(1977). Comparative study of dorsal motor of Vagus nerve American. J. Vet. Rec. 38:37-49

20.Smolen, A. J. and Raymond, C.T. (1977). The dorsal motor nucleus of Vagus nerve of Cat localization of the Preganglionc neuron by quantitative histology method. Anatomy. Record 189:555-586

21.De Lahunta, A. (1977). Veterinary neuroanatomy and clinical neurology. (W. B. 
Sounders comp. philadelphia, London) .

22.Adel K.Afifi, and Ronald, A. (1986). Basic neuro- science (2nd Edition). A structure and functional approach. The university of Lowa Lowa city. Lowa.

23. Abbas, T. A. (1986). Topographical and histological studies on the brain of one huped camel (Camelus Dormedarius) Thesis for master degree.

24.Ken -Ichiro toyoda, and Hiroyuki Okanono. (2006). Comparision of FGFI (aFGF) Expression between the dorsal nucleus of Vagus and hypoglossal nucleus of Rat. J. list . actahisto chem Dytochem . V.39 (1); Mar.2,2006 